\title{
BIRMINGHAM UNIVERSITY RADIOCARBON DATES III
}

F. W. SHOTTON, D. J. BLUNDELL, and R. E. G. WILLIAMS

\author{
The University of Birmingham, Birmingham, England
}

Measurements have continued with the $6 \mathrm{~L}$ counter. A counter of similar design but with $1 \mathrm{~L}$ volume has recently been brought into operation. Despite replacement of the teflon parts, the $1.5 \mathrm{~L}$ Oeschgertype counter has not worked consistently and has not been used for dating. Results are not corrected for $\delta \mathrm{C}^{13}$. Errors quoted refer only to the standard deviation calculated from a statistical analysis of count rates and the Libby half-life of $5570 \pm 30 \mathrm{yr}$.

Alkali pretreatment is used for all samples of charcoal, peat, wood, and plant material provided they are of sufficient quantity. It is now standard practice to boil the sample in $5 \% \mathrm{HCl}$ solution and filter, both before and after boiling it in $2 \% \mathrm{NaOH}$ solution. Between each treatment it is washed in boiling distilled water and is finally oven dried at $110^{\circ} \mathrm{C}$. Concentrations of acid and alkalis are varied to suit each sample but the sequence of the pretreatment is always the same. In some cases a humate extract is obtained by precipitation with weak acid from the alkali solution filtrate.

The collagen fraction is obtained from samples of bone using the method of Krueger (1966) by treatment with dilute acid under reduced pressure. The gas evolved during the treatment is usually discarded but is occasionally retained and dated as the mineral fraction.

After mechanical cleaning, samples of shell are dissolved in stages with $6 \mathrm{~N} \mathrm{HCl}$ to divide them into two or three fractions corresponding to the outer, middle, and inner layers of the shell. Normally the outer fraction is discarded when three fractions have been prepared.

\section{SAMPLE DESCRIPTIONS}

I. BRITISH ISLES FULL-GLACIAL

\section{Birm-57. Burland, Cheshire}

Plant remains washed from silt in core sample between 27.5 and $37.5 \mathrm{~m}$ depth from Burland Borehole $\left(53^{\circ} 04^{\prime} 40^{\prime \prime} \mathrm{N}\right.$ Lat, $2^{\circ} 35^{\prime} 40^{\prime \prime}$ W Long, grid ref. SJ602533; Poole and Whiteman, 1966, p. 106). Silts overlain by pebbly clays, sands, and gravel including 4 separate horizons recorded as boulder clay. Coll. 1959 by Geol. Surv.; subm. by F. W. Shotton. Contained insect fauna is temperate suggesting interglacial age for silts, which radiocarbon date confirms.

\section{Birm-60. Great Ryton, Shropshire}

Marine mollusc shells imbedded in medium-coarse sand $1.6 \mathrm{~m}$ thick at $5 \mathrm{~m}$ depth beneath beds of sand and gravel. Sample from $\mathrm{W}$ facing wall of gravel pit $\left(52^{\circ} 37^{\prime} \mathrm{N}\right.$ Lat, $2^{\circ} 45^{\prime} \mathrm{W}$ Long, grid ref. SJ490035). Coll. 1967 and subm. by G. S. Boulton. Samples subm. to provide maximum age for Kame and Kettle deposits in which shells occur. 
Birm-75. Great Billing, Northamptonshire

$28,230 \pm 330$

26,280 B.C.

Lens of peat and organic silt containing Coleoptera in $3 \mathrm{~m}$ thick Nene Gravels which overlie Lias clay and underlie $1 \mathrm{~m}$ alluvial clay. Sample $1 \mathrm{~m}$ above base of gravels at Great Billing $\left(52^{\circ} 14^{\prime} 45^{\prime \prime} \mathrm{N}\right.$ Lat, $0^{\circ} 47^{\prime} 30^{\prime \prime}$ W Long, grid ref. SP617826). Coll. 1968 and subm. by Anne Morgan. Sample dates insect fauna and Nene Gravels and affirms reliability of Coleoptera as stratigraphic indices (Morgan, 1969).

Birm-77. Mochras, Merionethshire

Lignitic plant remains in silty clay from borehole at Mochras $\left(52^{\circ}\right.$ $48^{\prime} 30^{\prime \prime} \mathrm{N}$ Lat, $4^{\circ} 08^{\prime} 20^{\prime \prime} \mathrm{W}$ Long, grid ref. SH553259) at $100.4 \mathrm{~m}$ depth under $53 \mathrm{~m}$ of boulder clay (Wood and Woodland, 1968). Coll. 1968 and subm. by A. Wood. Originally claimed as Pleistocene, now regarded as Cainozoic.

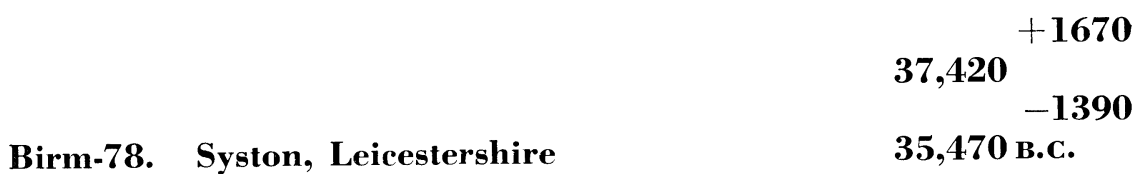

Plant fragments from lens of silty clay at $4 \mathrm{~m}$ depth in gravels overlying Keuper Marl and underlying Holocene alluvium at Pontylue Gravel Pit, Syston (52 $42^{\prime} \mathrm{N}$ Lat, $1^{\circ} 06^{\prime} \mathrm{W}$ Long, grid ref. SK609112). Coll. 1968 by T. Riley; subm. by R. J. Rice. Sample indicates gravels of Upton Warren Interstadial age beneath Holocene alluvium in Soar Valley.

Birm-86. Earith, Huntingdonshire

$>45,000$

Plant remains (Sample E9) from peat lens in terrace gravels of $\mathbf{R}$. Ouse at Earith $\left(52^{\circ} 22^{\prime} 0^{\prime \prime} \mathrm{N}\right.$ Lat, $0^{\circ} 02^{\prime} 30^{\prime \prime} \mathrm{W}$ Long, grid ref. TL390763). Coll. 1965 and subm. by F. C. Bell.

$$
\begin{aligned}
& 42,140+1890 \\
& \multicolumn{1}{c}{-1530} \\
& 40,190 \text { в.C. }
\end{aligned}
$$

Birm-88. Earith, Huntingdonshire Plant remains (Sample E7a) from peat lens in terrace gravels of $\mathrm{R}$.

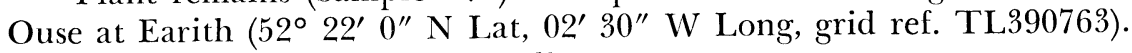
Coll. 1965 and subm. by F. C. Bell.

\section{Birm-89. Newtown, Co. Waterford, Ireland} $>38,000$

Wood pieces separated from peat in silt believed beneath Ballyvoyle Till, but relationship obscured by slumping. Silt attributed to Gortian (Hoxnian) by Watts (1959) but suggested as early Holocene (Zone VIa) by Orme (1966, p. 134). Sample from Newtown, Co. Waterford $\left(52^{\circ} 08^{\prime}\right.$ N Lat, $7^{\circ} 02^{\prime}$ W Long), coll. 1968 and subm. by F. W. Shotton. Date excludes Holocene and therefore supports Gortian age. 
Birm-108. Dimlington Cliff, Yorkshire

$18,240 \pm 250$ lington Cliff (53० $40^{\prime} 25^{\prime \prime} \mathrm{N}$ Lat, $0^{\circ} 05^{\prime} 25^{\prime \prime} \mathrm{E}$ Long, grid ref. TA393217), (Catt and Penny, 1966). Coll. 1968 and subm. by L. F. Penny. Insufficient material for full alkali pretreatment but sample boiled in dilute HCl, washed and dried. Confirms date on sample from same silt, 18,500 \pm 400 (I-3372, unpubl.), and proves 3 superimposed tills, all late-Weichselian.

II. BRITISH LATE-GLACIAL AND HOLOCENE

\section{Birm-55. Brandesburton, Yorkshire}

$12,850 \pm 250$ 10,900 в.C.

Collagen from antler of Megaceros giganteus (Blumenbach) dug up by mechanical excavator from $1.2 \mathrm{~m}$ thick Late Glacial/Holocene (Zone III-IV) shell-marl overlying Weichselian gravels (Clark and Godwin, 1957) at Catfoss Pit, Brandesburton $\left(53^{\circ} 54^{\prime} 12^{\prime \prime} \mathrm{N}\right.$ Lat, $0^{\circ} 16^{\prime} 14^{\prime \prime}$ W Long, grid ref. TA133467). Coll. 1967 and subm. by P. J. Boylan. Antler older than containing deposit and so derived.

\section{Birm-87. Thrapston, Huntingdonshire}

$$
8920 \pm 160
$$

6970 в.c.

Plant remains from Carex peat erratic in terrace gravels of R. Nene at Thrapston $\left(52^{\circ} 24^{\prime} 40^{\prime \prime} \mathrm{N}\right.$ Lat, $0^{\circ} 32^{\prime} 10^{\prime \prime} \mathrm{W}$ Long, grid ref. SP995802). Coll. 1967 and subm. by F. C. Bell.

\section{Birm-101. Beddington Park, Surrey}

$10,130 \pm 120$

Plant fragments washed from peaty silt layer at $1.5 \mathrm{~m}$ depth between beds of coarse roughly stratified gravel mapped by Geol. Survey as Taplow Terrace ( 1 in. Geol. Surv. Sheet $270,51^{\circ} 21^{\prime} 15^{\prime \prime} \mathrm{N}$ Lat, $0^{\circ}$ 08' 45" W Long, grid ref. TO292652). Coll. 1968 and subm. by D. S. Peake. Coleoptera suggest Late-Glacial rather than older cold period. Possible root contamination but date confirmatory of Late-Glacial (Zone III).

III. BRITISH ANTARCTIC SURVEY

\section{Birm-48. King George Island}

(a) $9670 \pm 230$ 7720 B.C.

(b) $8790 \pm 260$ 6840 B.C.

Inner (a) and middle (b) fraction of marine mollusc shell from gravel beneath till, Potter Cove $\left(62^{\circ} 14^{\prime} \mathrm{S}\right.$ Lat, $58^{\circ} 41^{\prime} \mathrm{W}$ Long) at concrete reservoir $\mathrm{W}$ of refuge huts (same loc. as Birm-23; $7683 \pm 86$, Radiocarbon, 1968, v. 10, p. 203 but lower horizon). May indicate onset of marine regression and early stage of glacial readvance that culminated in deposition of overlying till. Coll. 1966 and subm. by B. S. John. Difference of 2 determinations suggests some isotopic replacement has occurred. 
Birm-49. King George Island

(a) $2810 \pm 550$

860 B.c.

(b) $674 \pm 66$

A.D. 1276

Mineral (a) and collagen (b) fractions of vertebrae from decomposing whale washed onto W Beach, Three Brothers Hill Peninsula $\left(62^{\circ} 15^{\prime}\right.$ S Lat, 58 41' W Long) between 1965 and 1966. Coll. 1966 and subm. by B. S. John. Reflects $\mathrm{C}^{14}$ deficiency in Antarctic waters (Broeker, 1963).

\section{VOLCANIC DEPOSITS}

Birm-90. Sao Miguel, Azores

$4435 \pm 99$

2485 B.C.

Charcoal buried by trachytic ash (Saō Miguel Fogo Member A) from large Plinian-type eruption of Fogo Volcano, from roadside gully $3 \mathrm{~km} \mathrm{~S}$ of Porto Formosa $\left(37^{\circ} 47^{\prime} 30^{\prime \prime} \mathrm{N}\right.$ Lat, $25^{\circ} 26^{\prime} \mathrm{W}$ Long). Coll. 1967 and subm. by G. P. L. Walker. Dates one of most extensive and voluminous ash layers on the island.

\section{Birm-91. Sao Miguel, Azores}

$5990 \pm 110$

4040 B.c.

Charcoal from top of coastal cliff, midway between Fenais de Luz and Rabo de Peixe ( $37^{\circ} 49^{\prime} \mathrm{N}$ Lat, $25^{\circ} 36^{\prime} \mathrm{W}$ Long). Sample on soil immediately beneath basalt lava flow, one of youngest flows in "waist" fissure zone of island derived from Mata do Leal Crater. Coll. 1967 and subm. by G. P. L. Walker.

v. MiscellaneOUS GEOLOGIC SITES

Birm-61. Lake Katwe, Uganda

\section{A.D. 1008}

$942 \pm 66$

Fossil wood from mud layer in salt crust $1.1 \mathrm{~m}$ beneath floor of Lake Katwe $\left(0^{\circ} 08^{\prime} \mathrm{S}\right.$ Lat, $29^{\circ} 53^{\prime} \mathrm{E}$ Long, U.T.M. grid ref. RK1885). Coll. and subm. by W. H. Morton. Rate of accumulation of salts estimated from age of sample.

Birm-68. Sorgfjord, Vestspitsbergen

$10,940 \pm 190$ 8990 B.C.

Shells (Mya arctica) from $0.7 \mathrm{~m}$ depth in raised beach at $+33 \mathrm{~m}$ alt beside Sorgfjord $\left(79^{\circ} 50^{\prime} \mathrm{N}\right.$ Lat, $16^{\circ} 50^{\prime} \mathrm{E}$ Long). Coll. 1965 by M. Rhodes; subm. by G. S. Boulton. Date useful for rate of isostatic uplift.

Birm-76. Piazza del Duomo, Pisa, Italy

$$
+\mathbf{1 5 0 0}
$$

(a) 35,880

33,930 в.c.

$$
-1180
$$

(b) 36,400

$\mathbf{3 4 , 4 5 0}$ в.c.

$+1550$

$-1200$

Outer (a) and inner (b) fraction of shells (Cardium edule) from Layer D of Lower Clays, 29.3 to $30.1 \mathrm{~m}$ depth $(-26.3$ to $-27.1 \mathrm{~m}$ alt), 
below likely weathering surface in possible Mid-Würm Interstadial sequence at Piazza del Duomo (43 $43^{\prime} \mathrm{N}$ Lat, $10^{\circ} 24^{\prime} \mathrm{E}$ Long). Coll. and subm. by A. W. Skempton. From horizon dated previously, Pi-7a $26,360 \pm 1400$ (Radiocarbon, 1959, v. 1, p. 109).

Birm-83. Ship Creek, S Westland, New Zealand

$+1760$

(a) 43,470

41,520 в.C.

(b) 32,800

$+1400$

30,850 в.c.

Sample after alkali pretreatment (a) and humate extract (b) of water-worn twigs in carbonaceous silt from Sardine Terrace rd. sec. 1/2 $\mathrm{km} \mathrm{N}$ of Ship Creek, S Westland (43 $45^{\prime} \mathrm{S}$ Lat, $169^{\circ} 10^{\prime}$ E Long). Terrace ca. $+50 \mathrm{~m}$ alt. in tectonically rising area. Coll. 1968 and subm. by F. W. Shotton. Silt overlies boulder layer on Tertiary basement and underlies laminated silt, probably glacial.

(a) 35,380

$+2830$

$$
\text { 33, } 430 \text { B.C. }
$$

\section{Birm-94. Puerto Viejo, Chile}

(b) 34,760

$+2410$

32,810 B.c.

Outer (a) and inner (b) fractions of shells (Mactracea) from $1 \mathrm{~m}$ depth in unconsolidated shell bank, $2 \mathrm{~m}$ thick, covered by blown sand. Bank forms marine terrace at $+-80 \mathrm{~m}$ alt ca. $1 \mathrm{~km}$ inland at mouth of Rio Copiapó, Puerto Viejo (27 ${ }^{\circ} 21^{\prime} \mathrm{S}$ Lat, $70^{\circ} 57^{\prime} \mathrm{W}$ Long). Coll. 1966 and subm. by C. Mortimer.

\section{Birm-95. Monte Amargo, Chile}

$1018 \pm 73$

Peat at $0.5 \mathrm{~m}$ below top of river terrace bordering $\mathrm{S}$ bank of Rio Copiapó, near Monte Amargo (27 $22^{\prime}$ S Lat, $70^{\circ} 43^{\prime} \mathrm{W}$ Long). Sample from carbonaceous layer in silts and sands $3.5 \mathrm{~m}$ above present level of flood plain. Coll. 1967 and subm. by C. Mortimer.

\section{ARCHAEOLOGIC SAMPLES}

\section{A. British}

\section{Bromfield series, Shropshire}

Samples from Middle Bronze age cemetery at Bromfield $\left(52^{\circ} 23^{\prime}\right.$ N Lat, $2^{\circ} 46^{\prime} \mathrm{W}$ Long, grid ref. SO480778). Coll. 1966 and subm. by S. C. Stanford. 
Birm-62.

Charcoal from cremation pit at $0.5 \mathrm{~m}$ depth assoc. with typologically late form urn. Gives terminal date of cemetery and also for 40 vessels represented there.

Birm-63.

$2800 \pm 71$

Charcoal from cremation pit at $0.5 \mathrm{~m}$ depth assoc. with early type urn. Dates introduction of Wessex type burial urns into central Welsh border.

\section{Birm-64.}

$3510 \pm 180$

Charcoal from cremation pit at $0.5 \mathrm{~m}$ depth. Dates introduction of globular decorative features into central Welsh border.

\section{Birm-65.}

$3940 \pm 100$

Charcoal from pre-barrow scoop at $0.7 \mathrm{~m}$ depth. Date sets earlier limit to age of barrow which appears to be primary element in cemetery.

\section{Birm-69. Beckery, Glastonbury, Somerset}

$1185 \pm 80$

Collagen fraction of part of human skeleton $0.3 \mathrm{~m}$ deep in Blue Lias clay with some bands of thin limestone. Grave covered by floor levels of later stone chapel. This is earliest, and most important, grave in small cemetery of early Christian monastic site at Beckery $\left(51^{\circ} 09^{\prime}\right.$ $\mathrm{N}$ Lat, $2^{\circ} 44^{\prime} \mathrm{W}$ Long, grid ref. ST487385). Coll. 1967 and subm. by P. A. Rahtz. Nothing else on site can be dated with certainty earlier than 10th century but this sample proves earlier period.

\section{Birm-70. Cannington, Somerset}

$1220 \pm 110$

Collagen fraction of part of skeleton of adolescent girl from grave near mouth of R. Parrett $\left(51^{\circ} 09^{\prime} \mathrm{N}\right.$ Lat, $3^{\circ} 06^{\prime} \mathrm{W}$ Long, grid ref. ST252405). Grave is covered by mound which became shrine, approached by well-worn path surrounded by 350 graves (Wilson and Hurst, 1964, p. 237). Coll. 1963 and subm. by P. A. Rahtz. Sample dates beginning of cemetery.

\section{Birm-85. Ysgwennant, Denbighshire}

$3423 \pm 82$

Charcoal from burial pit, assoc. with beaker sherds usually dated ca. 1800 в.C., from Bronze age burial mound at $\mathrm{W}$ end of Field 984a (25 in. O.S. map Denbs: XL11. 10, Edn. of 1912) near Ysgwennant $\left(52^{\circ}\right.$ $51^{\prime} 57^{\prime \prime} \mathrm{N}$ Lat, $3^{\circ} 12^{\prime} 14^{\prime \prime} \mathrm{W}$ Long, grid ref. SJ189305). Coll. 1961 and subm. by W. Day. 


\section{B. Non-British}

Birm-71. Dumpo Quarter, Brong/Ahafo, Ghana A.D. 1020

$930 \pm 160$

Charcoal from lower level of occupation mound near top of Spit 6 , Dumpo Quarter ( $7^{\circ} 56^{\prime} 30^{\prime \prime} \mathrm{N}$ Lat, $2^{\circ} 26^{\prime} \mathrm{W}$ Long). Coll. 1967 and subm. by D. Mathewson. Sample from sealed occupation floor underlying higher level, dates lst occupation.

\section{Birm-79. Dumpo Quarter, Brong/Ahafo, Ghana}

$$
\delta \mathbf{C}^{14 \%} \%=+\mathbf{1 3 . 9} \pm \mathbf{1 2 . 2}
$$

Charcoal from bottom of Spit 11 in occupation mound at Dumpo

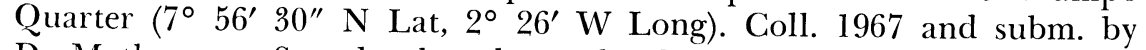
D. Mathewson. Sample thought to be from earliest occupation level but is clearly modern.

\section{Birm-80. Dumpo Quarter, Brong/Ahafo, Ghana A.D. 1299}

$651 \pm 95$

Charcoal from top of Spit 9 in occupation mound at Dumpo Quarter $\left(7^{\circ} 56^{\prime} 30^{\prime \prime} \mathrm{N}\right.$ Lat, $2^{\circ} 26^{\prime} \mathrm{W}$ Long). Coll. 1967 and subm. by $\mathrm{D}$. Nathewson.

\section{Birm-72. Morphou, Cyprus}

\section{Black deposit probably hearth material, from Neolichic site at}

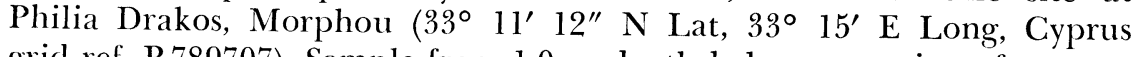
grid ref. R789707). Sample from $1.0 \mathrm{~m}$ depth below succession of occupation deposits overlying "havara" Limestone. Coll. 1967 and subm. by P. S. Gelling.

\section{Birm-81. Rivoli, Verona, Italy}

$1140 \pm 180$

Charcoal assoc. with burnt cereal grains in upper filling of Neolithic pit at Rivoli $\left(45^{\circ} 50^{\prime} \mathrm{N}\right.$ Lat, $11^{\circ} 20^{\prime} \mathrm{E}$ Long). Regarded as intrusive possibly from overlying Early Bronze age level (Barfield, 1966). Coll. 1966 and subm. by L. H. Barfield. Radiocarbon date implies material much younger than imagined.

\section{Bagarawiya series, Sudan}

Charcoal samples from ancient Meroe (now Bagarawiya) $\left(17^{\circ} 50^{\prime}\right.$ N Lat, $34^{\circ} 10^{\prime}$ E Long), $230 \mathrm{~km} \mathrm{~N}$ of Khartoum. Coll. 1968 and subm. by P. L. Shinnie.

Birm-97. Sample MR-7

Dates earliest occupation in 1 part of same stratum.

\section{Birm-98. Sample MR-8}

$$
2230 \pm 120
$$

Subm. to date earliest occupation of another part of site and assoc. iron working and gives starting point for pottery sequence. 
Birm-99. Sample MR-6

Subm. to fix date in stratigraphic and pottery sequence.

Subm. to fix date in stratigraphic and pottery sequence.

\section{Birm-100. Sample MR-5}

$2980 \pm 140$

1030 B.c.

Subm. to fix date in stratigraphic and pottery sequence.

\section{REFERENCES}

Date lists:

$\begin{array}{ll}\text { Birmingham II } & \text { Shotton, Blundell, and Williams, } 1968 \\ \text { Pisa I } & \text { Ferrara, Reinharz, and Tongiorgi, } 1959\end{array}$

Barfield, L. H., 1966, Excavations on the Rocca di Rivoli: Mus. Civico di Storia Nat. di Verona, Mem. v. 14, p. 1-100.

Broeker, W. S., 1963, Radiocarbon ages of Antarctic materials: Polar Record, v. 11, no. 73 , p. 472 .

Catt, J A and Penny, L. F., 1966, The Pleistocene deposits of Holderness, Yorkshire: Yorkshire Geol. Soc. Proc., v. 35, p. 375-408.

Clark, J. G. D. and Godwin, H., 1957, A Maglemosian site at Brandesburton, Holderness, Yorkshire: Prehist. Soc. Proc., v. 22, p. 6-22.

Ferrara, G., Reinharz, M., and Tongiorgi, E., 1959, Carbon-14 dating in Pisa: Am. Jour. Sci. Radiocarbon Suppl., v. 1, p. 103-110.

Krueger, H. W., 1966, The preservation and dating of collagen in ancient bones, in: Proc. 6th Internatl. Conf. radiocarbon and tritium dating, 1965, Pullman, Washington, p. 332-337.

Morgan, Anne, 1969, A Pleistocene fauna and flora from Great Billing, Northamptonshire, England: Opusc. Entomol. Lund, v. 34, p. 109-129.

Orme, A. R., 1966, Quaternary changes of sea-level in Ireland: Inst. British Geog. Trans. and Papers, no. 39, p. 127-143.

Poole, E. G. and Whiteman, A. J., 1966, Geology of the country around Nantwich and Whitchurch: Great Britain, Geol. Surv. Mem., no. 122.

Shotton, F. W., Blundell, D. J., and Williams, R. E. G., 1968, Birmingham University radiocarbon dates II: Radiocarbon, v. 10, p. 200-206.

Watts, W. A., 1959, Interglacial deposits at Kilbeg and Newtown, Co. Waterford: Royal Irish Acad. Proc., v. 60, sec. B, p. 79-134.

Wilson, D. M. and Hurst, D. G., 1964, Medieval Britain in 1962 and 1963: Medieval Archaeol., v. 8, p. 231-299.

Wood, A. and Woodland, A. W., 1968, Borehole at Mochras, W of Llanbedr, Merionethshire: Nature, v. 219, p. 1352-1354. 